\title{
Comparative Anatomy of the Absorption Roots of Terrestrial and Epiphytic Orchids
}

\author{
Ana Sílvia Franco Pinheiro Moreira* and Rosy Mary dos Santos Isaias \\ Universidade Federal de Minas Gerais; Instituto de Ciências Biológicas; Departamento de Botânica; \\ moreira_ana@yahoo.com.br; 31270-901; Belo Horizonte-MG - Brasil
}

\begin{abstract}
The present study compared roots of terrestrial and epiphytic Orchidaceae, analyzing the anatomical characteristics from an ecological point of view. The material was collected at three different sites in Minas Gerais / Brazil and was fixed in FAA. Transverse sections were obtained by freehand sections or from material previously embedded in Paraplast $®$ or Historesin $\Theta$. The prominent characteristics of the epiphytic group were: significant smaller perimeter, epidermis with 3 or more cell layers, $U$-thickened exodermal cell walls, O-thickened endodermal cell walls, and a low ratio between the caliber and the number of protoxylem arches. The terrestrial group presented simple or multiseriate epidermis, and exodermis and endodermis with typical Casparian strips. The anatomical characteristics should have evolved with several adaptations to distinct environments during evolutionary process.
\end{abstract}

Key words: Orchids, terrestrial, epiphytic, anatomy, adaptations

\section{INTRODUCTION}

The Orchidaceae constitute one of the largest families of flowering plants, having around 20,000 species. They are unique in forms, colors and flower structure. However, the vegetative organization is variable among the species (Dressler, 1993). In general, they are composed of adventitious roots, rhizome, stem, leaves, floral ramets, and flowers (Kramer, 1975).

During evolutionary process, the orchids have become adapted to distinct environments, so they can be epiphytes, terrestrials, saprophytes or lithophytes (Black, 1973). These environmental variations contribute for structural alterations in vegetative organs (Pabst and Dungs, 1975).

The epiphytic orchids constitute at about $75 \%$ of all the other Orchidaceae species (Atwood, 1986).
They have aerial roots with the function of fixation on substrate, and water and minerals absorption. The terrestrial species absorb their nutrients direct from the soil, and may present three kinds of roots: (1) one adapted to absorption, and fixation; (2) a tuber adapted to nutritive substances storage, and (3) one specialized in storage, absorption, and fixation (Black, 1973). According to Dressler (1993), the tubers are able to survive during dry season, and nourish the plant when it is necessary. The Orchidaceae are subdivided into five subfamilies: Apostasioideae, Cypripedioideae, Epidendroideae, Spiranthoideae, and Orchidoideae (Dressler, 1993). The ten species presently studied belongs to the last three groups. Spiranthoideae and Orchidoideae are constituted mostly of terrestrial species, and so have adaptive characteristics to soil environment, while

\footnotetext{
${ }^{*}$ Author for correspondence
} 
Epidendroideae species are mostly epiphytes (Dressler, 1993).

Even though the orchids are considered a derived group, some primitive characteristics may be observed. The reduced size of their seeds is efficient for plant dispersion in environments of difficult colonization, and the flowers specialization to ornitophyly and entomophyly are characteristics to be considered (Robinson and Burns-Balogh, 1982). These authors suggested that the subfamilies Spiranthoideae, Apostasioideae, and Orchidoideae can be viewed as a succession of forms that have reverted to the terrestrial habits from epiphytic ancestry.

This research compares terrestrial and epiphytic Orchidaceae absorption roots, analyzing their anatomical characteristics in relation to the environment.

\section{MATERIALS AND METHODS}

The terrestrial orchids: Habenaria petalodes Lindl., Prescottia montana Barb.Rodrig., Prescottia oligantha Lindl. and Sauroglossum nitidum (Vell.) Schltr., and the epiphytic orchids: Epidendrum saxatile Lindl., Encyclia patens Hook., Lanium avicula Lindl., Polystachya estrellensis Rchb. f., Sophronitis pumila (Hook) Van den Berg and M.W.Chase and Scaphyglottis modesta Schltr. were collected at Serra da Calçada, Brumadinho/MG, and Serra do Caraça, Catas Altas/MG. Twenty samples of the roots of each species were fixed in FAA 50 for 48 hours and then transferred to ethanol $50 \%$ (Johansen, 1940).

The perimeter $(p)$ of twenty roots of each species were calculated by the formula $p=2 \pi r$. The diameter of the roots at $2 \mathrm{~cm}$ from the apex was obtained with a caliper Digimess ${ }^{\circledR}$ and used to calculate de radius by the formula $d=2 r$. The perimeter:protoxylem arches ratio $(p / p x)$ was calculated to estimate the relative water and nutrients conduction from the root cortex to the other parts of the plant.

Histological slides were prepared by freehand sections or from material previously embedded in Paraplast ${ }^{\circledR}$ and/or Leica ${ }^{\circledR}$ historesin. The freehand sections were obtained using a razor blade, and stained with $0.5 \%$ astra blue and safranin $(2: 8)$ (Kraus and Arduin, 1997). The slides were mounted in Haupt glycerinate gelatin (Kraus and Arduin, 1997).

Root fragments were dehydrated in buthyl or ethyl series (Johansen, 1940) and embedded in Paraplast ${ }^{\circledR}$ (Kraus and Arduin, 1997) or Leica ${ }^{\circledR}$ Historesin. Transverse sections were cut on a Leica Jung Biocut $^{\circledR}$ microtome, with 5-6 $\mu \mathrm{m}$ thickness for Historesin and $10-14 \mu \mathrm{m}$ for Paraplast ${ }^{\circledR}$ embedded material. The sections were stained with $0.5 \%$ astra blue and safranin $(2: 8)$ or $0.5 \%$ toluidine blue (Kraus and Arduin, 1997), and mounted in Entellan ${ }^{\circledR}$.

Root sections were analyzed in light microscope. Photomicrographs were obtained in an Olympus BH2-BHS photomicroscope.

\section{RESULTS}

\section{Terrestrial orchids}

Most of the terrestrial orchids have tubers, while Habenaria petalodes has dimorphic roots; one for absorption and soil fixation, and other for nutrient storage. In this research just the absorption roots were analyzed and are described in sequence.

Habenaria petalodes (fig. 1). Hairs unicellular. epidermis uniseriate (fig. 11). Exodermis uniseriate. Cortex 7-9 cells wide, parenchymatic, with mycorrhizae sparsely disposed inside cells; cells of 3-4 layers subtending epidermis with reduced intercellular spaces, small size, thin walled, with raphids. Cells of inner 4-5 layers circular, with triangular intercellular spaces, higher sizes. Endodermis uniseriate, with inconspicuous Casparian strips. Vascular cylinder 10-arch, inconspicuous xylem and phloem strands. Pith cells mostly circular, thin walled, reduced intercellular spaces. The perimeter:protoxylem arches ratio was 0.63 .

Prescottia oligantha (fig. 2). Velamen 3-4 cell layers, with thick walls and supporting strips. Exodermis uniseriate. Cortex 15-17 cells wide. Cells thin walled, variable in size. Cells 2-3 layers subtending exodermis and 3-4 layers off endodermis with raphids. Little storage starch grains. Endodermis uniseriate with conspicuous Casparian strips (fig. 15). Vascular cylinder 4arch, xylem and phloem easily distinguishable. Pith cells mostly circular with no intercellular spaces. The perimeter:protoxylem arches ratio was 3.94 . 
Prescottia montana (fig. 3). Velamen 2-3 cell layers, with thin walls and supporting strips. Exodermis uniseriate. Cortex 14-16 cells wide, parenchymatic; cells of regular shapes and sizes, with triangular intercellular spaces. All cells thinwalled. Raphids in 1-2 cell layers subtending exodermis and nearby endodermis. Pelotons in parenchymatic cells next to the site of fixation to the substrate and storage starch grains. 2-6 layers nearby endodermis with raphids (fig. 14). Endodermis uniseriate, cells isodiametric, with conspicuous Casparian strips. Vascular cylinder 11-arch, xylem scarcely distinguished within phloem strands. PITH cells mostly circular with thick walls and reduced intercellular spaces. The perimeter:protoxylem arches ratio was 2.40 .

Sauroglossum nitidum (fig. 4). Hairs unicellular. velamen 9-10 cell layers (fig. 12), with thick walls and supporting strips. Exodermis uniseriate, cells polygonal, with no apparent thickening. Cortex 17-24 cells wide, parenchymatic; small cells of 1-3 cell layers subtending exodermis with some raphids; the next 10-12 cell layers circular and of higher sizes; cells of inner layers reduced in size, with raphids and starch grains. Endodermis uniseriate, with evident Casparian strips. Vascular cylinder 17-arch of intercalated strands of xylem and phloem. Pith cells mostly circular, thick walled, with triangular intercellular spaces and raphids. The perimeter:protoxylem arches ratio was 1.77 .

\section{Epiphytic orchids}

Encyclia patens (fig. 5). Velamen 10-12 cell layers with thin walls and inconspicuous supporting strips. Exodermis U-thickened with conspicuous passage cells. Cortex 8-9 cells wide, parenchymatic; cells isodiametric, mostly same size, but evidently smaller subjacent to the endodermal and exodermal layers. Cells phithickened (fig. 16). Cells of 3-4 cell layers subtending the exodermis with raphids. Endodermis O-thickened, clusters of passage cells opposite to xylem arches. Vascular cylinder 21arch, intercalated

strands of xylem and phloem surrounded by lignified cells. Pith cells mostly circular with thin walls and triangular intercellular spaces. The perimeter:protoxylem arches ratio was 0.46 .

Epidendrum saxatile (fig. 6). Velamen 3-4 cell layers, with thick walls. Exodermis U-thickened (fig. 60), passage cells intermittent. Cortex 12-14 cells wide, parenchymatic. Cells circular, thin walled, with raphids. Endodermis O-thickened, passage cells opposite to the protoxylem arches (fig. 17). Vascular cylinder 14-arch, with intercalated strands of xylem and phloem. PITH cells mostly circular with triangular intercellular spaces. The perimeter:protoxylem arches ratio was 0.52 .

Sophronitis pumila (fig. 7). Velamen 4-5 cell layers, with thin walls and supporting strips. Exodermis uniseriate, U-thickened. Cortex 8-12 cell wide, parenchymatic; cells variable in size, with thin walls, raphids, little starch grains and mycorrhizae in cells closer to the substrate (fig. 18). Endodermis uniseriate, O-thickened. Clusters of passage cells opposite to xylem arches. Vascular cylinder 16-arch, intercalated strands of xylem and phloem surrounded by lignified cells. Pith cells circular, with thin walls and triangular intercellular spaces. The perimeter:protoxylem arches ratio was 0.47 .

Polystachia estrellensis (fig. 8) roots were star shaped in transverse section. Velamen 3 cell layers with supporting strips. Exodermis uniseriate, cells domed, mostly isodiametric, U-thickened. Tilosomes disposed near passage cells (fig. 20). Cortex 8-16 cells wide, parenchymatic, cells thin walled with triangular intercellular spaces filled with mucilage-like substance. Hiphae might be immersed in this substance (fig. 19). Thick walled cell layers subtending exodermis, storage raphids (fig. 19), and starch grains. Endodermis uniseriate, O-thickened, with clusters of 3-4 grouped passage cells. Vascular cylinder 11-arch, intercalated strands of xylem and phloem surrounded by lignified cells. PITH of reduced dimension, cells circular, thin walls and triangular intercellular spaces. The perimeter:protoxylem arches ratio was 0.88 .

Lanium avicula (fig. 9). Velamen biseriate with supporting strips (fig. 13). Exodermis Uthickened. Cortex 4-5 cells wide, parenchymatic; cell layers subtending exodermis and endodermis of smaller size. Intermediate cell layers circular, thin walled, with intercelular spaces. Endodermis uniseriate, O-thickened (fig. 21). Vascular cylinder 15-arch, with intercalated strands of xylem and phloem, surrounded by lignified cells. Pith cells mostly circular, with thick walls, and no intercellular spaces. The perimeter:protoxylem arches ratio was 0.17 .

Scaphyglottis modesta (fig. 10). Velamen 4 cell layers, with hiphae of fungi, mostly concentrated near passage cells of exodermis. Exodermis 
uniseriate, O-thickened. Passage cells isolated. Cortex 6-8 cells wide, parenchymatic, with micorrhizae. Cells subtending exodermis and endodermis of reduced size. Cells of intermediate layers circular to oval, with thin walls. Endodermis uniseriate, O-thickened. Vascular cylinder 12- arch. Intercalated strands of xylem and phloem surrounded by lignified cells. Pith cells mostly circular, lignified, with no intercellular spaces. The perimeter:protoxylem arches ratio was 0.36 .

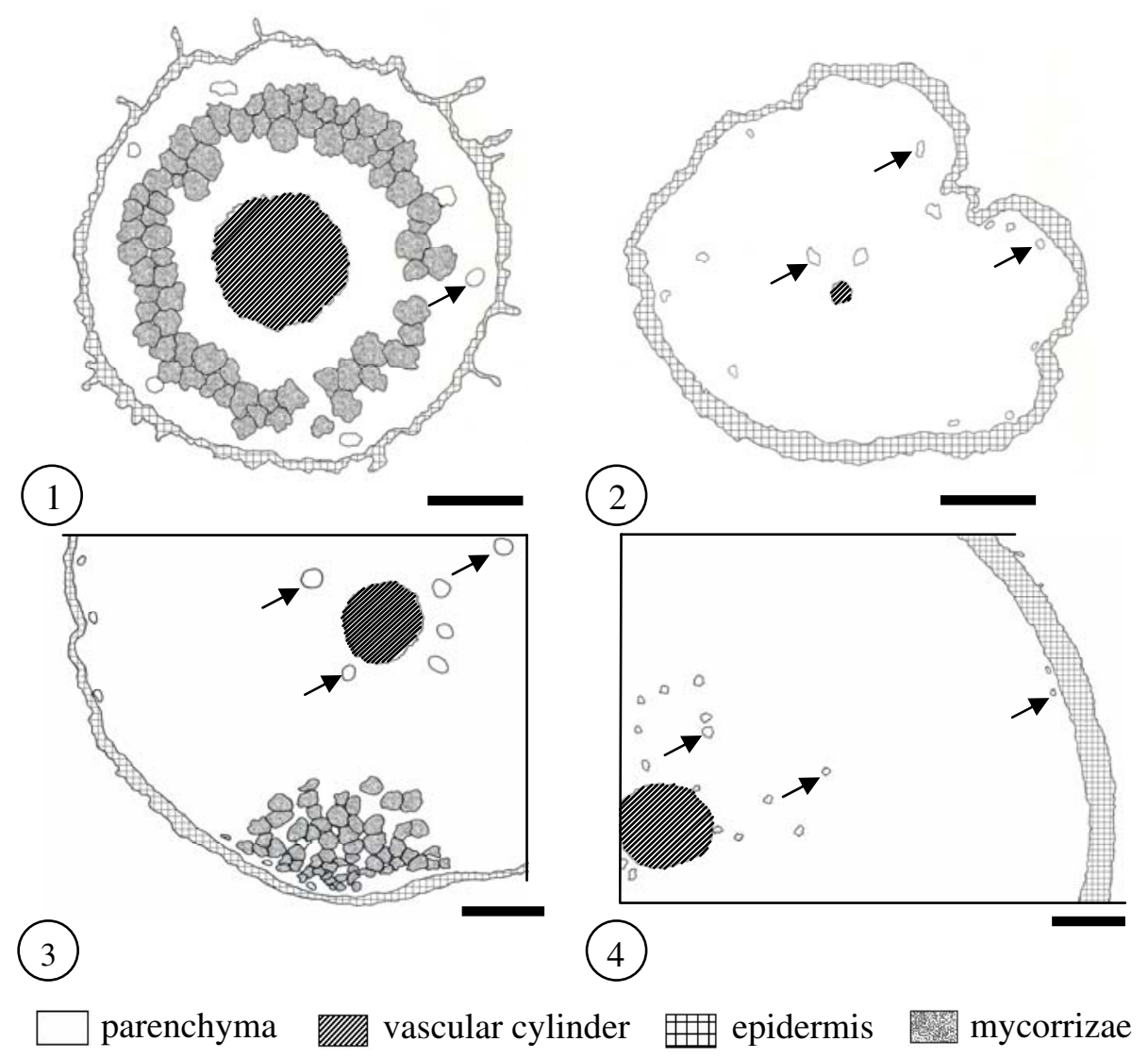

Figures 1-4 - Absorption roots diagrams of terrestrial orchids. 1) Habenaria petalodes. 2) Prescottia oligantha. 3) Prescottia montana. 4) Sauroglossum nitidum. Arrows indicate raphids. (bars $=0.5 \mathrm{~mm}$ in 1 ; and $1 \mathrm{~mm}$ in $2-4$ ) 


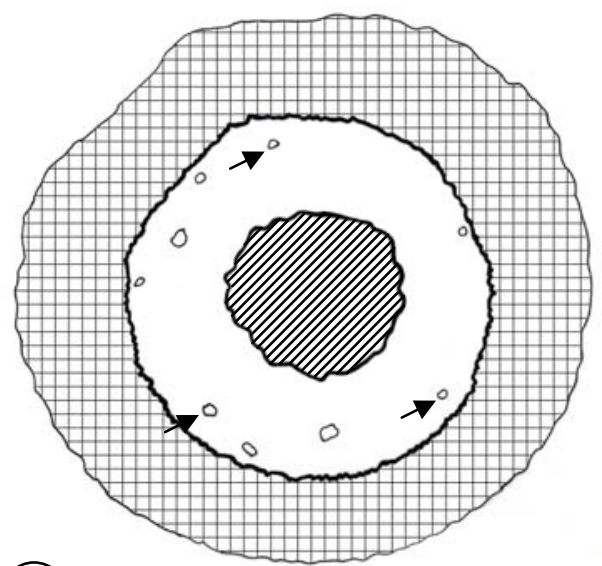

(5)



(7)

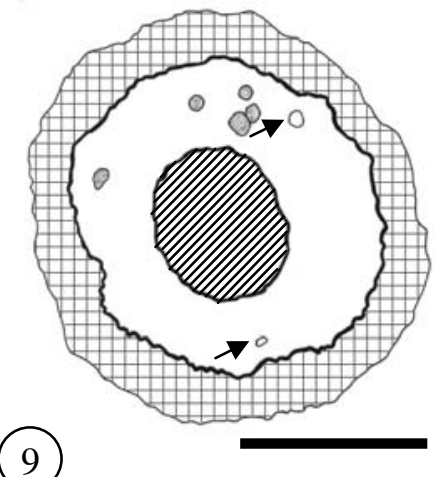

$\square$ parenchyma

YIIIM vascular cylinder

曲 velamen

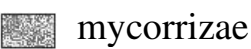
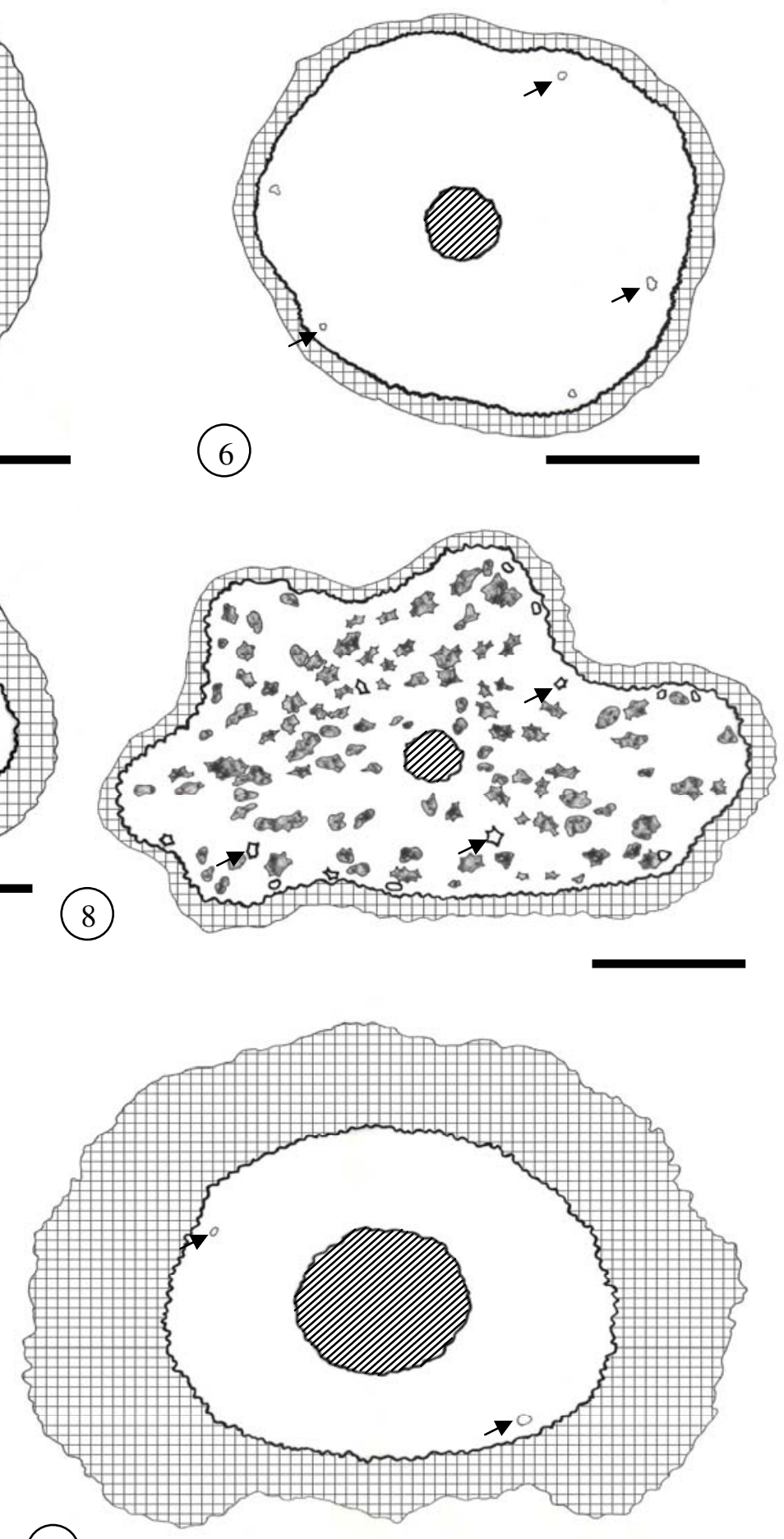

(10)

Figures 5-10 - Absorption roots diagrams of epiphytic orchids. 5) Encyclia patens. 6) Epidendrum saxatile. 7) Sophronitis pumila. 8) Polystachia estrellensis. 9) Lanium avicula. 10) Scaphyglottis modesta. Arrows indicate idioblasts with raphids. (bars $=1 \mathrm{~mm}$ in $5-8$; and $0.4 \mathrm{~mm}$ in $9-10$ ) 


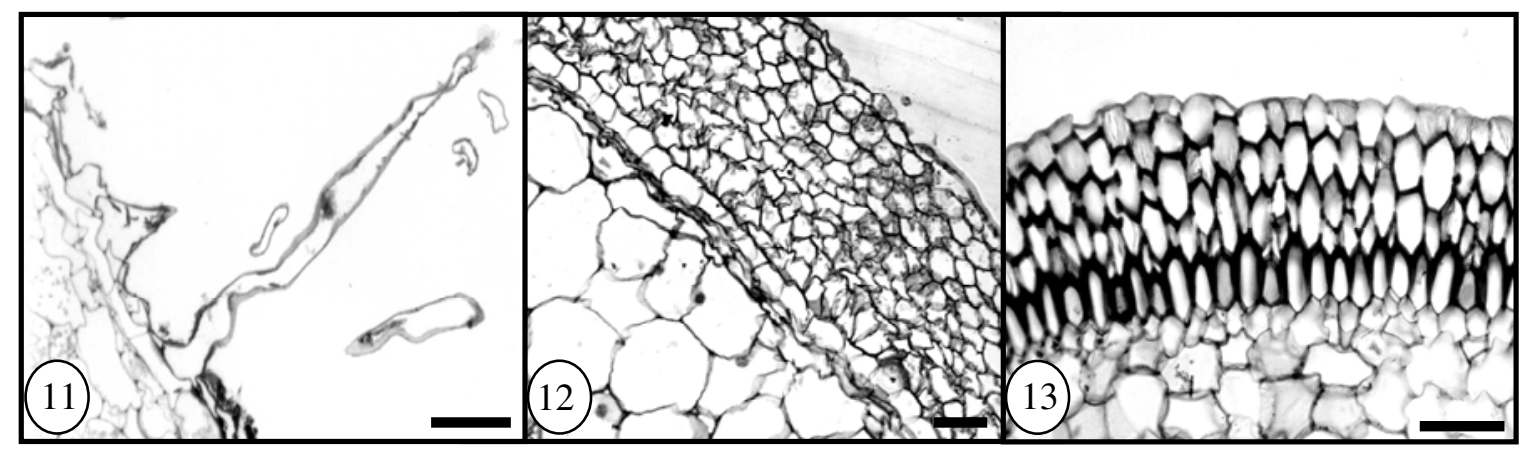

Figures 11-13 - 11) Uniseriate epidermis in Habenaria petalodes. 12) Velamen and exodermis ir Sauroglossum nitidum. 13) Velamen and U-thickened exodermis in Laniun avicula. (bars $=100 \mu \mathrm{m})$

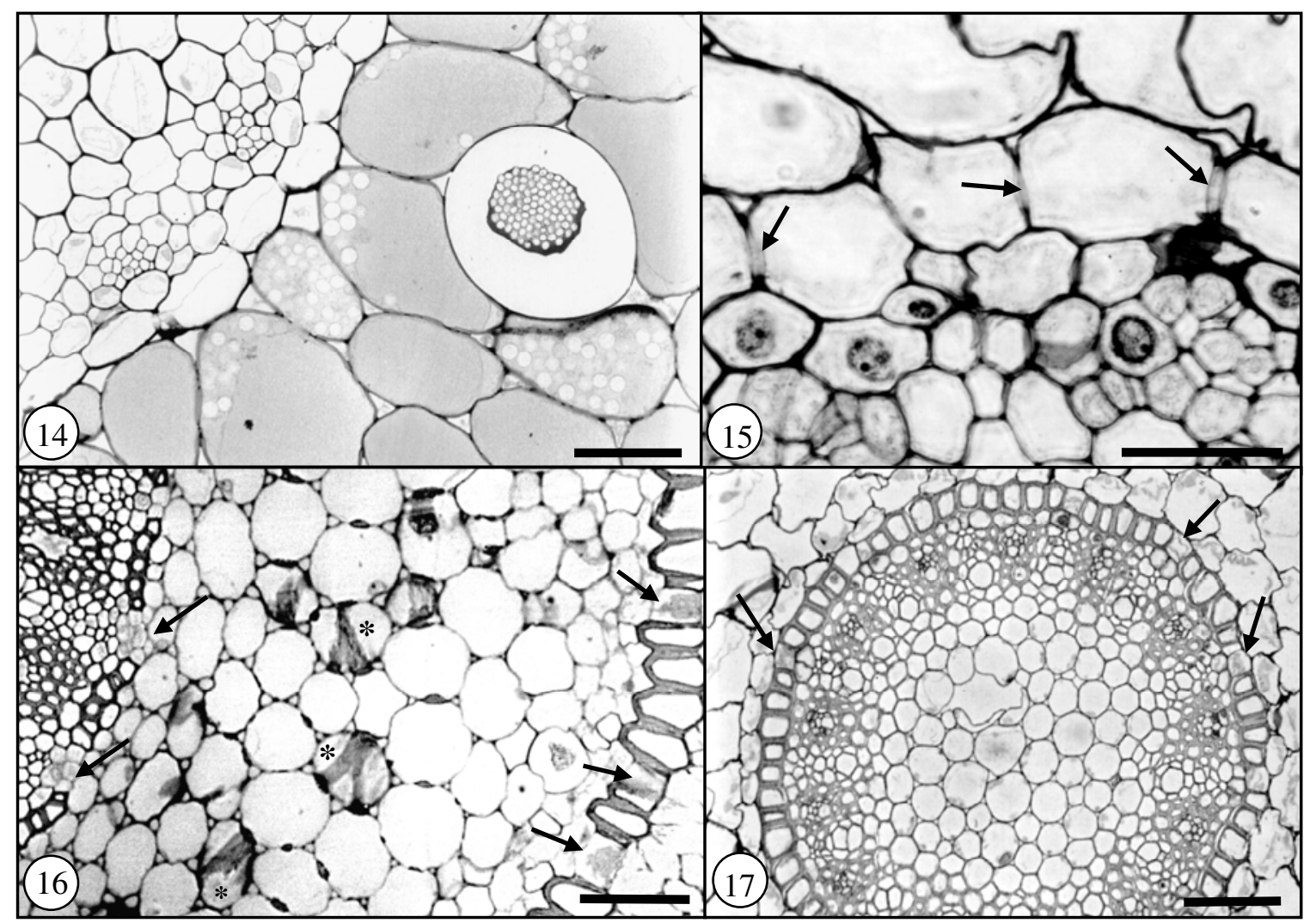

Figures 14-17 - 14) Detail of raphid near endodermis and starch grains in the cortex of Prescottia montana. 15) Casparian strips (arrows) in the endodermis of Prescottia oligantha. 16) phi- thickened $(*)$ parenchymatic cells in Encyclia patens, the arrows indicate passage cells in endodermis e exodermis. 17) $\mathbf{O}$-thickened endodermis, passage cells (arrows) opposite to the protoxylem arches in Epidendrum saxatile. (bars = $100 \mu \mathrm{m}$ in $14,16-17$; and $50 \mu \mathrm{m}$ in 15$)$ 


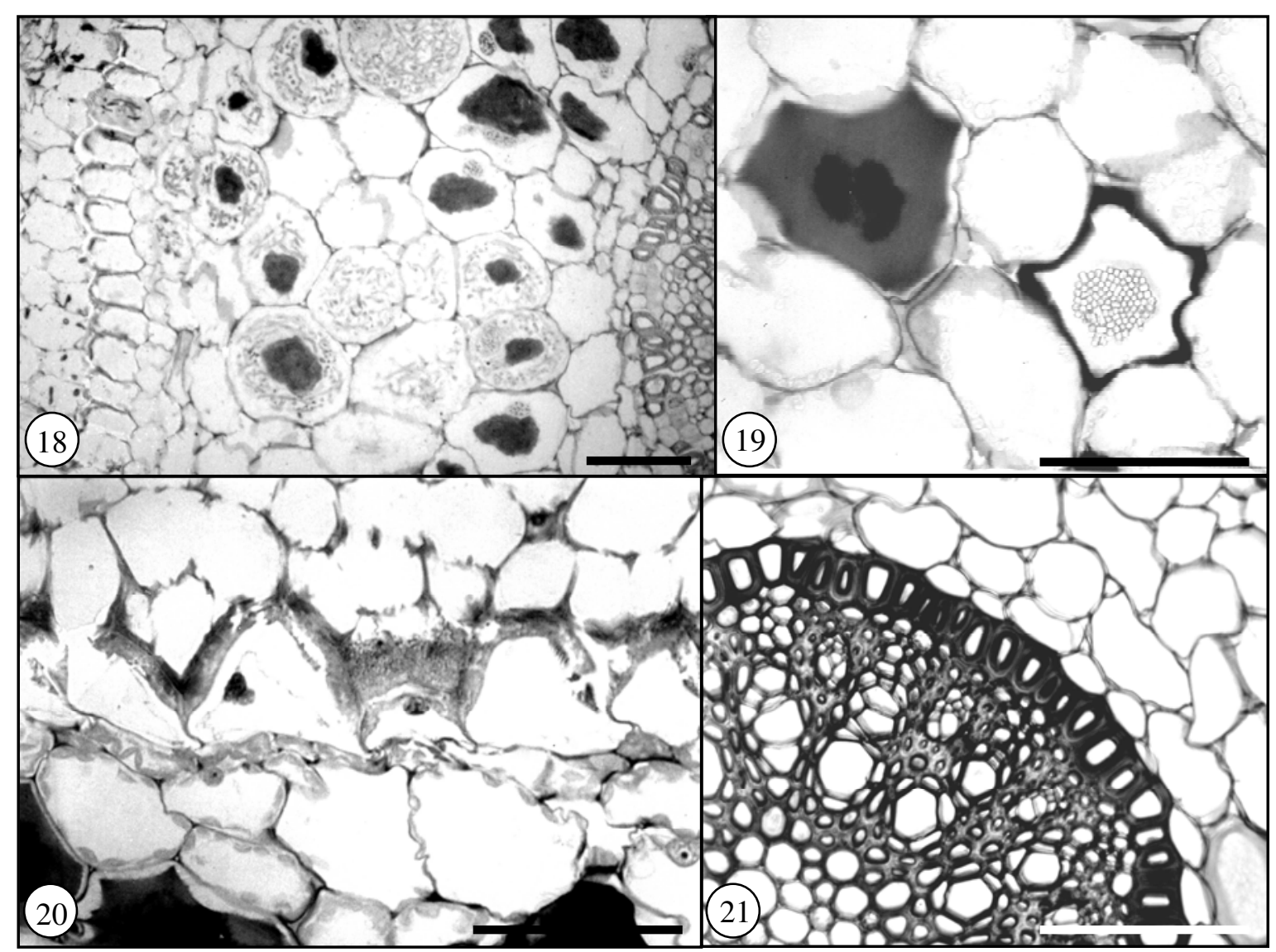

Figures 18-21 - 18) Sophronitis pumila with cortex mycorrhizae forming pelotons. 19) Raphids in thick walled idioblasts and fungi imerse in a mucilage-like substance in Polystachia estrellensis. 20) U-thickened exodermis and tilosome (arrows) in P. estrellensis. 21) Lanium avicula O-thickened endodermis. (bars $=100 \mu \mathrm{m})$

Table 1 - Variation in root perimeter, number of protoxylem arches, and perimeter/protoxylem arches ratio in absorption roots of terrestrial and epiphytic orchids.

\begin{tabular}{lccc}
\hline \multicolumn{1}{c}{ Orchidacae species } & Perimeter* $(\mathbf{m m})$ & Protoxilem arches & $\begin{array}{c}\text { Perimeter/protoxylem arches } \\
\text { ratio }\end{array}$ \\
\hline Habenaria petalodes & $6.33 \pm 0.32$ & 10 & 0.63 \\
Prescottia montana & $26.41 \pm 1,04$ & 11 & 2.40 \\
Prescottia oligantha & $15.77 \pm 1.70$ & 4 & 3.94 \\
Sauroglossum nitidum & $30.20 \pm 2.87$ & 17 & 1.77 \\
\hline Encyclia patens & $9.63 \pm 0.57$ & 21 & 0.46 \\
Epidendrum saxatile & $7.39 \pm 1.89$ & 14 & 0.52 \\
Lanium avicula & $2.62 \pm 0.49$ & 15 & 0.17 \\
Polystachia estrellensis & $9.73 \pm 1.46$ & 11 & 0.88 \\
Sophronitis pumila & $7.62 \pm 0.96$ & 16 & 0.47 \\
Scaphyglottis modesta & $4.34 \pm 0.73$ & 12 & 0.36 \\
\hline
\end{tabular}

*Average ( \pm standard deviation) in twenty roots of each species. 


\section{DISCUSSION}

All the studied species have similar root structure, with parenchymatic pith involved by a variable number of xylem and phloem strands, endodermis with or without evident Casparian strips, parenchymatic cells, exodermis, and simple epidermis or velamen. However, distinct tissue distribution, cell shapes, and number of cell layers can be noted.

The diameter of the roots of the terrestrial Orchidaceae is wider than that of the epiphytic ones. This characteristic can be associated with the storage of nutritive substances and water (Zots, 1999). Habenaria roots have the smallest diameter when compared to the other species, at least in terms of absorption roots. The function of storing substances in this species is concentrated in tubers. The star form of $P$. estrellensis roots may amplify the contact of root surface with the substrate and with the atmosphere, facilitating water, and possibly nutrients absorption, as well.

The root dermal system may consist of a single or of many cell layers, morphologically and physiologically distinct (Fahn, 1990). The velamen, a multiple seriate dermal system, is formed by dead cells at maturity. The number of cell layers does not change with different environmental conditions, however, the rate of maturation, size of cells and hence thickness of the velamen can be markedly altered (Oliveira and Sajo, 1999; Dycus and Knudson, 1957). Many functions are attributed to this tissue, like amplifying access to mineral-rich solutions (Benzing et al., 1982), reducing transpiration, reflecting infrared radiation, offering substantial mechanical protection (Benzing et al., 1982; Pridgeon, 1986), and exchanging oxygen and carbon dioxide between the root and atmosphere (Dycus and Knudson, 1957; Sanford and Adanlawo, 1973). The significantly higher number of cell layers in $S$. nitidum velamen when compared to the other terrestrial orchids may be related to their bigger diameter, and can also amplify the mechanical protection. Benzing et al. (1982) believe that the orchids velamen act as a sponge, allowing the root to immobilize a temporary but rightly accessible reservoirs of moisture and minerals, however brief its contact with precipitation or canopy leachates. The presence of velamen is observed in almost all of the studied species, except in $H$. petalodes where there is just a simple epidermis. This feature has been described by Stern (1997) for $H$. distans and $H$. repens, even though it is not present in all Habenariinae species.

According to Dressler (1993), the velamen is, generally, spongy, and with fibrous thickened cell walls. This thickness appears to confirm on a rather large scale the hypothesis that the functions of the velamen are water conservation (Sanford and Adanlawo, 1973), inhibition of cellular collapse during periods of desiccation (Pridgeon, 1986), and mechanical protection (Noel, 1974). The velamen fibrous thickened cell walls are observed in all of the studied species.

The tilosomes observed in P. estrellensis are near passage cells and may be considered an important feature. This structure permits water absorption, possibly prevent the entry of pathogens (Holtzmeier et al., 1998), and reduce root transpiration (Benzing et al., 1982; Benzing et al. 1983). Benzing et al. (1982) call attention for the fact that the movements of substances beyond the velamen may be partially blocked by the presence of these fibrous bodies. At the bottom of them, however, the extent of solid wall between the velamen dead space and the root symplast is much thinner than at any other point along the exodermis-velamen interface (Benzing et al. 1982). Tilosomes are previously referred by Pridgeon et al. (1983) for the epiphytic group as an adaptative feature.

The exodermis is the outer layer of cortex (Engard, 1944), and may be constituted, in transverse section, of long and short cells alternately disposed. The long cells develop thick secondary walls, and are empty and dead at maturity (Pridgeon, 1986). Wall thickening of exodermal cells is frequently caused by lignin and suberin deposition (Fahn, 1990). It provides mechanical protection, and the provision of a high-humidity envelope around the cortex (Benzing et al. 1983; Sanford and Adanlawo, 1973). The shorter cells, called passage cells, are thin walled and living at maturity, what makes them important to the nutrition, and hydration of the epiphytic orchids. The passage cells in the exodermis attract endomycorrhizal fungi and are thus capable of ion uptake, once the velamen and the other exodermal cells are dead (Peterson and Enstone, 1996; Senthilkumar et al. 2000a). The terrestrial orchids 
exodermis in the studied species exhibit just Casparian strips in their walls, what facilitates water and nutrients absorption, while the exodermis of epiphytic species exhibit $\mathbf{U}$ and $\mathbf{O}$ thickness.

The parenchymatic cortex in the studied terrestrial orchids is wider than the vascular cylinder, except for $H$. petalodes. The presence of tubers in this species can influence the structure of main roots, once just the tubers have cortical development. This result may be related to the highest water and nutritive storage in terrestrial orchids.

In $E$. patens, there are branched phi-thickenings in cortical cell walls. These kind of cell wall thickenings have been already described by Haas et al. (1976) in Pelargonium roots. To Dickison (2000), these thickenings have cellulosic, lignin or condensate tannin origin, with the function of mechanical support, water regulation or ions transport through the apoplast.

Raphids of calcium oxalate are observed in all the studied terrestrial and epiphytic orchids, except in $L$. avicula and $S$. modesta. The crystal idioblasts have different forms and characteristic wall thickenings. In $P$. montana, these cells are conspicuously cylindrical, while in the other studied species they present the same shape of the cortical cells. $P$. estrellensis idioblasts have cellulosic cell wall thickenings, noted by purplish color when toluidine blue is used (O'Brien and McCully, 1981). The calcium oxalate crystals have many different functions, like storage forms of calcium and oxalic acid, plant defense, ionic balance, osmotic regulation, and calcium levels in the sieve elements regulation (Franceschi and Horner, 1980; Bonates, 1993; Paiva and Machado, 2005). Prychid and Rudall (1999) believe there is calcium oxalate resorption in times of calcium depletion.

Many studies have showed symbiotic relation between fungi and orchids. According to Zots (1999), this kind of relation is common among Orchidaceae. To Senthilkumar and Krishnamurthy (1998), there are different kinds of micorritics associations if the site of fungi installation in root cortex is taken into consideration. The orchids have a special kind of endomycorrizae where the hyphae of fungi make characteristics pelotons inside cortical cells. The pelotons form intracellular bodies which are digested by their host cells, and are important for plant nutrition (Lesica and Antibus, 1990; Senthilkumar et al., 2000b). In this research, mycorrizae are observed in almost all studied species, except in $P$. oligantha and $S$. modesta. Senthilkumer et al. (2000a) affirm that mycorrizae cannot be detected in the stele or in endodermal cells, and that pelotons may be present just in cortical cells, what is coherent with our observations in S. pumila, $P$. montana, H. petalodes, and P. estrellensis. For these authors, the hiphae penetrate root cortex through exodermal passage cells (which can control the passage of these fungi). In $S$. modesta, this fact can be easily noted, and the presence of hiphae is evident in velamen cells concentrated, especially, near passage cells regions.

The purple colored substance detected in the cortex cells of $P$. estrellensis may be of pectic nature, for toluidin blue stains alginates and pectic substances in purple (O'Brien and McCully, 1981).

All the epiphytic orchids studied show secondary thickening in endodermal cells. This thickening, as described by Fahn (1990) and Mauseth (1988), is deposited over the Casparian strips by additional deposition of suberin and lignin. The endodermal thickenings constitute an efficient apoplastic barrier to water and nutrients ( $\mathrm{Ma}$ and Peterson 2003). So, just like in the exodermal layer, the presence of passage cells in endodermis is necessary.

The vascular cylinder exhibits similar characteristics in all the studied species. Xylem and phloem strands are intercalated and involve a central parenchymatic pith. The xylem arches are located in the direction of passage cells in endodermis, which facilitates water and nutrient transport to the rest of the plant. All of the studied species were considered medulated monosteles.

In general, the analysis of some of the structures discussed above is too interesting and may relate these plants to their habits. The presence of velamen in epiphytic orchids is fundamentally important to facilitate water and nutrients absorption. Lignified exodermis and endodermis comply intensive mechanical protection against water evaporation, and control the entrance of mycorrizae in cortical cells. The terrestrial habit implies less structural adaptations for water deficit. The perimeter:protoxylem arches ratio calls special attention. The higher number of protoxylem arches related to root size observed in epiphytic roots, may be a response to the necessity of efficient substances transport to the rest of the plant. This efficient transportation possibly compensates the absence of storage tissues. So, in 
terrestrial orchids transportation may be slower as the nutrients are available nearby. The presence of velamen, lignified exodermis and endodermis, and a higher number of protoxylem arches in relation to root size are important characteristics for an efficient colonization of the epiphytic environment.

The morphological characteristics of terrestrial and epiphytic orchids feed constant discussions about the origin of orchids (Porembski and Barthlott, 1988; Robinson and Burns-Balogh, 1982). The evolution of this group of plants has been discussed for a long time, but even nowadays it is difficult to establish all the points of the process. The variety of morphological, anatomical and physiological traits in orchids maintains the uncertainty about the primitive characteristics or derivates features.

\section{ACKNOWLEDGEMENTS}

The authors would like to thank CAPES for financial support and the biologists Rubens Custódio da Motta and Pedro Lage Vianna for taxonomical contributions.

\section{RESUMO}

O presente trabalho comparou raízes de Orchidaceae epífitas e terrestres, analisando as características sob um ponto de vista ecológico. O material foi coletado em três diferentes regiões de Minas Gerais/Brasil e fixado em FAA. Cortes transversais foram obtidos à mão livre ou em material infiltrado em Paraplast ou Historresina. As principais características do grupo epifítico foram: perímetro significativamente menor, epiderme com 3 ou mais camadas celulares, exoderme com espessamento em $\mathrm{U}$, endoderme com espessamento em $\mathrm{O}$ e uma baixa razão entre o calibre e o número de pólos de protoxilema. $\mathrm{O}$ grupo terrestre apresentou epiderme simples ou bisseriada e exoderme e endoderme com estrias de Caspary. As características anatômicas podem estar envolvidas com diferentes adaptações aos distintos ambientes durante o processo evolutivo.

\section{REFERENCES}

Atwood, J. T. (1986), Two new species in the Maxillaria rufescens complex from Central America. Lindleyana, 11, 27-33.

Benzing, D. H.; Friedman, W. E.; Peterson, G. and Renfrow, A. (1983), Shootlessness, velamentous roots, and the pre-eminence of Orchidaceae in the epiphytic biotipe. American Journal of Botany, 70(1), 121-133.

Benzing, D. H.; Ott, D. W. and Friedman, W. E. (1982), Roots of Sobralia macrantha (Orchidaceae): structure and function of the velamen-exodermis complex. American Journal of Botany, 69(4), 608614.

Black, P. M. (1973), Orquídeas. Ed. Ao Livro Técnico S/A. Rio de Janeiro.

Bonates, L. C. M. (1993), Estudos ecofisiológicos de Orchidaceae da Amazônia. II - Anatomia ecológica foliar de espécies com metabolismo CAM de uma campina da Amazônia central. Acta Amazonica, 23(4), 315-348.

Dickison, W. C. (2000), Integrative plant anatomy. Harcourt Academic Press, USA.

Dressler, R. L. (1993), Phylogeny and classification of the Orchid family. Cambridge University Press. Deoscorides Press, Oregon.

Dycus, A. M. and Knudson, L. (1957), The role of the velamen of the aerial roots of orchids. Botanical Gazette, 119, 78-87.

Engard, C. J. (1944), Morphological identity of the velamen and exodermis in orchids. Botanical Gazette, 105, 457-462.

Fahn, A. (1990), Plant anatomy. Pergamon Press, Oxford.

Franceschi, V. R. and Horner, H. T. (1980), Calcium oxalate crystals in plants. Botanical Review, 46, 361427.

Haas, D. L.; Carothers, Z. B. and Robbins, R. R. (1976), Observations on the phi-thickenings and Casparian strips in Pelargonium roots. American Journal of Botany, 63(6), 863-867.

Holtzmeier, M. A.; Stern, W. L. and Judd, W. S. (1998), Comparative anatomy and systematics of Senghas's cuschion of Maxillaria (Orchidaceae). Botanical Journal of the Linnean Society, 127, 4382.

Johansen, D. A. (1940), Plant microtechnique. McGraw Hill Book Co, New York.

Kramer, J. (1975), Orchids. H. N. Abrams Publishers, New York.

Kraus, J. E. and Arduin, M. (1997), Manual básico de métodos em morfologia vegetal. Editora da Universidade Federal Rural do Rio de Janeiro, Seropédica.

Lesica, P. and Antibus, R. K. (1990), The occurrence of mycorrhizae in vascular epiphytes of two Costa Rican rain forests. Biotropica, 22(3), 250-258. 
Ma, F. and Peterson, C. A. (2003), Current insights into the development, structure and chemistry of the endodermis and exodermis of roots. Canadian Journal of Botany, 81, 405-421.

Mauseth, J. D. (1988), Plant anatomy. Benjamin/Cumming. Menlo Park.

Noel, A. R. A. (1974), Aspects of cell wall structure and the development of the velamen in Ansellia gigantean Reichb. f. Annals of Botany, 38, 495-504.

O'Brien, T. P. and McCully, M. E. (1981), The study of plant. Structure principles and selected methods. Termarcarphi Pty, Melbourne.

Oliveira, V. C. and Sajo, M. G. (1999), Root anatomy of nine Orchidaceae species. Brazilian Archives of Biology and Technology, 42(4), 405-413.

Pabst, G. F. J. and Dungs, F. (1975), Orchidaceae Brasiliensis I. Hildesheim, Brucke-Verlag. Kurt Schmerson.

Paiva, E. A. S. and Machado, S. R. (2005), Role of intermediary cells in Peltodon radicans (Lamiaceae) in the transfer of calcium and formation of calcium oxalate crystals. Brazilian Archives of Biology and Technology, 84(1), 147-153.

Peterson, C. A. and Enstone, D. E. (1996), Functions of passage cells in the endodermis and exodermis of root. Physiologia Plantarum, 97, 592-598.

Porembski, S. and Barthlott, W. (1988), Velamen radicum micromorphology and classification of Orchidaceae. Nordic Journal of Botany, 8, 117-137.

Pridgeon, A. M.; Stern, W. L. and Benzing, D. H. (1983), Tilosomes in roots of Orchidaceae: Morphology and systematic occurrence. American Journal of Botany, 70(9), 1365-1377.

Pridgeon, A. M. (1986), Anatomical adaptations in Orchidaceae. Lindleyana, 1(2), 90-101.
Prychid, C. J. and Rudall, P. J. (1999), Calcium oxalate crystals in monocotyledons: A review of their structure and systematics. Annals of Botany, 84, 725739.

Robinson, H. and Burns-Balogh, P. (1982), Evidence for a primitively epiphytic habit in Orchidaceae. Sistematic Botany, 7(4), 353-358.

Sanford, W. W. and Adanlawo, I. (1973), Velamen and exodermis characters of West African epiphytic orchids in relation to taxonomic grouping and habit tolerance. Botanical Journal of the Linnean Society, 66, 307-321.

Senthilkumar, S.; Krishnamurthy, K. V.; Britto, S. J. and Arockiasamy, D. I. (2000a), Visualization of orchid mycorrhizal fungal structures with fluorescence dye using epifluorescence microscopy. Current Science, 79(11), 1527-1528.

Senthilkumar, S.; Britto, S. J.; Krishnamurthy, K. V. and Hariharam, C. (2000b). Biochemical analysis of mycorrhizal roots of Aerides maculosum. Phytomorphology, 50(3and4), 273-279.

Senthilkumar, S. and Krishnamurthy, K. V. (1998), A cytochemical study on the mycorrhizae of Spathoglottis plicata. Biologia Plantarum, 41(1), 111-119.

Stern, W. L. (1997), Vegetative anatomy of subtribe Habenariinae (Orchidaceae). Botanical Journal of the Linnean Society, 125, 211-227.

Zots, G. (1999), What are Backshoots good for? Seasonal changes in mineral, carbohydrate and water content of different organs of the epiphytic orchid, Dimerandra emarginata. Annals of Botany, 84, 791798. 